DOI: 10.17516/1997-1397-2020-13-4-459-465

УДК $539.231 ; 539.2526$

\title{
The Study of the Fine Structure of Ti-Al Coatings on the Surface of Ti, Obtained by Mechanical Alloying
}

\author{
Zhuldyz B. Sagdoldina \\ Baurzhan K. Rakhadilov \\ Riza B. Abylkalykova* \\ East Kazakhstan State University \\ Kamenogorsk, Kazakhstan \\ Lyudmila I. Kveglis ${ }^{\dagger}$ \\ Pavel O. Shalaev $\ddagger$ \\ Siberian Federal University \\ Krasnoyarsk, Russian Federation \\ Rauan S. Kozhanova \\ East Kazakhstan State University \\ Kamenogorsk, Kazakhstan
}

Received 27.12.2019, received in revised form 27.04.2020, accepted 10.06.2020

\begin{abstract}
The work is devoted to the study of structural-phase transformations in composite coatings (Ti-Al) + Ti during mechanical alloying. The data on the structural-phase states of (Ti-Al)-Ti coatings after mechanical alloying have been obtained, confirming the mechanism of formation of the modified layer due to deformation compaction of powder particles on the titanium surface under mechanical action. As a result of mechanochemical fusion, a $\mathrm{TiAl}_{3}$ phase with a bcc lattice $(14 / \mathrm{mmm}$ structure) was detected, which corresponds to the stable state of the $\mathrm{TiAl}_{3}$ alloy. Under conditions of mechanical alloying of the structure, $I 4 / \mathrm{mmm}$ transforms into the $L 1_{2}$ structure, which corresponds to the metastable state of $\mathrm{TiAl}_{3}$.
\end{abstract}

Keywords: structural phase transformations, composite coatings, mechanical alloying, solid phase processes.

Citation: Z.B. Sagdoldina, B.K. Rakhadilov, R.B. Abylkalykova, L.I. Kveglis, P.O. Shalaev, R.S. Kozhanova, The Study of the Fine Structure of Ti-Al Coatings on the Surface of Ti, Obtained by Mechanical Alloying, J. Sib. Fed. Univ. Math. Phys., 2020, 13(4), 459-465.

DOI: $10.17516 / 1997-1397-2020-13-4-459-465$.

\section{Introduction}

Currently, it is known that intermetallics represent a unique class of materials that retain an ordered structure up to the melting point, i.e., the melting and ordering temperatures coincide. Long-range order provides a stronger interatomic bond.

\footnotetext{
*rabylkalykova@mail.ru

${ }_{\dagger}^{\dagger}$ kveglis@list.ru

${ }^{\ddagger}$ pshalaev@sfu-kras.ru

(C) Siberian Federal University. All rights reserved
} 
Of the large number of known intermetallic compounds, the greatest attention of both experimenters and theoreticians is attracted by alloys based on titanium and aluminum.

Alloys of the Ti-Al system retain their structure and strength at high temperatures, have good anticorrosion and antifriction properties, which are significantly superior to conventional metals. In addition, alloys of the $\mathrm{Ti}-\mathrm{Al}$ system have: high melting point, low density, high modulus of elasticity, resistance to oxidation and fire, high specific heat resistance [1,2].

Titanium aluminides are considered promising structural materials for high-temperature applications in modern industries, such as aerospace, automotive, shipbuilding and others.

High values of specific strength of Ti-Al compounds in comparison with nickel superalloys make titanium aluminides very promising for the production of components of modern aircraft engines and turbines, however, their corrosion resistance remains lower than desired. In addition, a balance between the mechanical properties of titanium aluminides and their resistance to external factors cannot always be achieved.

Recently, processes activated by mechanical action (mechanochemical synthesis, mechanical activation, mechanical fusion) have become the subject of intensive research in connection with their promising application in various industries, since they provide the creation of new nontraditional, environmentally friendly and less costly technologies compared to existing methods of coating metal surfaces, such as chemical and physical vapor deposition, self-propagating juice temperature synthesis, thermal spraying, sol-gel method, etc.

The use of mechanical alloying to obtain coatings on a metal surface is a new area of surface treatment. The idea of this method is to use the impact energy of a moving ball to coat metal surfaces. This method, due to the solid phase state of the process, has practically no restrictions on the combinations of the deposited and base metal, does not require special preparation of the surface of the samples, and has relatively low energy costs for coating [3].

Currently, there are more than dozens of models of mechanochemical interactions; nevertheless, up to now, an empirical approach has been used in the development of functional materials, since existing models cannot explain the entire set of experimental results. This is due to the fact that mechanochemical fusion (MF) is a complex process, since the dispersion, phase composition, defective structure, and mechanical properties of the reaction mixture continuously change during its mechanical processing. In the process of MF, the number of parameters involved is very large (time, size of grinding media, the ratio of the mass of balls to the mass of powder, temperature, surrounding atmosphere, amplitude and frequency of oscillations) [4]. The variety of types of equipment leads to a huge variety of possible machining modes. And therefore, the identification of the main regularities of the MF process, which serve to predict the state of the final product of machining, is still an unresolved problem.

The aim of the work is to study the structural-phase transformations in composite coatings $(\mathrm{Ti}-\mathrm{Al})+\mathrm{Ti}$ during mechanical alloying.

\section{Methodology and discussion of experimental results}

The sample for the study was obtained by mechanical alloying on a vibrating unit SVU2. A mixture of $\mathrm{Ti}+\mathrm{Al}$ powder under the influence of ball impacts was deposited (welded) on the surface of a substrate of technical pure titanium VT1-0 with dimensions of $7 \times 7 \times 2 \mathrm{~mm}$. The coating thickness was about 25-30 microns. Powder fraction size: Ti -45 microns; $\mathrm{Al}-5$ microns.

$\mathrm{X}$-ray phase studies of the samples were carried out on a DRON-6 diffractometer using $\mathrm{CuK} \alpha$ radiation. The image capture was carried out in the following modes: tube voltage $U=40 \mathrm{kV}$; 
tube current $I=20 \mathrm{~mA}$; exposure time $3 \mathrm{~s}$; capture step $0.02^{\circ}$. Processing and analysis of experimental data was carried out using the PDWIN4.0 software package (NPP «Burevestnik» St. Petersburg), using the attached database.

The phase composition and structural parameters of the samples were studied on an XRD6000 diffractometer using $\mathrm{CuK} \alpha$-radiation. An analysis of the phase composition was carried out using PDF4+ databases. The capture was carried out in the following modes: tube voltage $U=40 \mathrm{kV}$; tube current $I=30 \mathrm{~mA}$; exposure time $1 \mathrm{~s}$; capture step $0.02^{\circ}$.

The study of the microstructure and analysis of the chemical composition of the samples was carried out on a JCXA-733 «Superprobe» electron probe microanalyzer with an INCA Energy SEM 300 energy-dispersive microanalysis attachment, and on a JSM-6390 scanning electron microscope with an electronic probe attachment for local microanalysis.

In a vibrating installation SVU2, particles of Ti-Al powder are cold-welded to the surface of Ti under the influence of ball impacts. The Ti-Al powder particles were subjected to mechanical grinding and repeatedly repeated deformation, and densification on the Ti surface. Intensive energy supply by spheres accelerated chemical reactions and solid-phase diffusion, both in the coating and at the interface, which led to strong adhesion of a metal matrix with particles of Ti-Al powder.

As a result, a coating was formed on the surface - a layer of composite material having a nano- and microstructure, which are characterized by very high adhesion.

Figs. 1 and 2 show the results of Ti-Al coatings on the titanium surface obtained inside the vibration chamber in the light and dark field modes.

Fig. $1 \mathrm{a}-\mathrm{c}$ shows that in the cross section of the coating there are dark patches in the light matrix. This is evidenced by the distribution of elements over the thickness of the coatings. Under the action of impacts, $\mathrm{Al}+\mathrm{Ti}$ particles are driven into the Ti matrix, as a result of which a coating is formed.

This is more clearly evidenced by the images of the contact area between the dark and light parts of the coating, the substrate with the coating adhering at the top with different increases, and the image of the transition coating-substrate layer shown in Fig. 2 a-c.

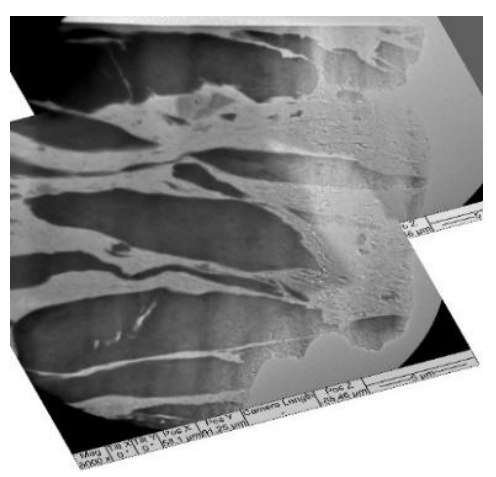

a)

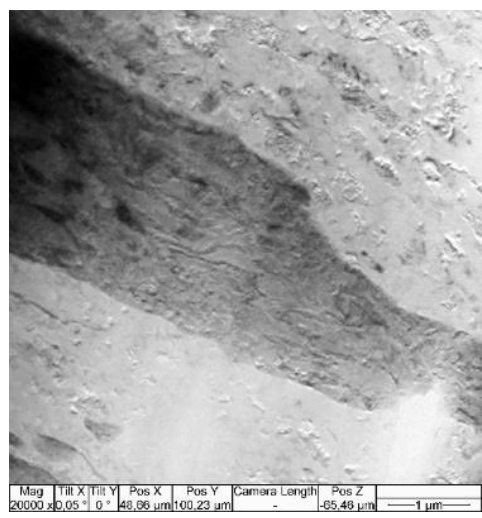

b)

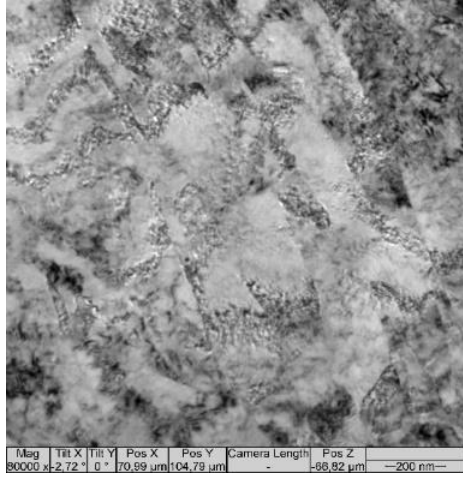

c)

Fig. 1. Cross section of the coating: a) - general view (there are dark areas in the light matrix), b) - and c) - an enlarged image of a dark area of the coating

Fig. 3 shows the images of the cross section (a) and the concentration profile of the cross section of the substrate (b). It is seen that during the formation of coatings, a process of 


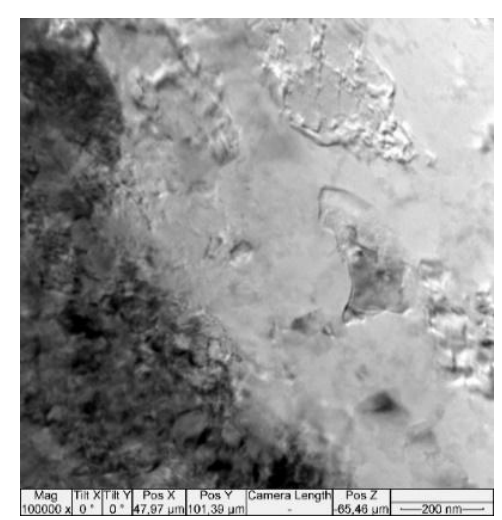

a)

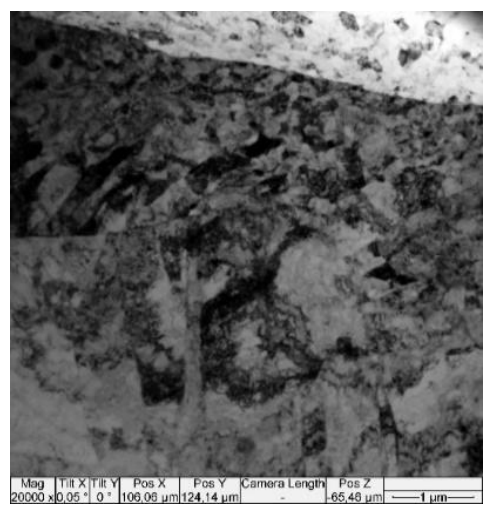

b)

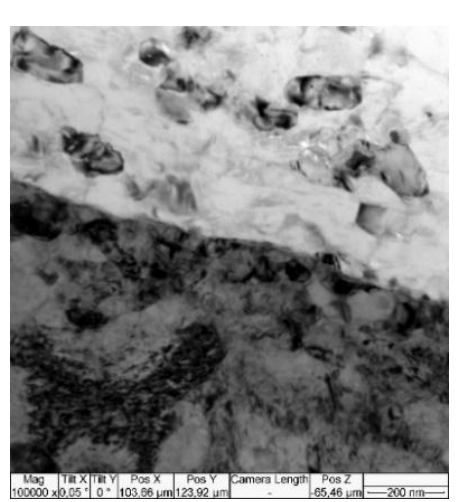

c)

Fig. 2. (a) The contact area of the dark and light areas of the coating. (b) Images of the substrate with a coating adhering on top at different magnifications. (c) The transition layer is coating-substrate

conglomeration of particles of $\mathrm{Ti}$ and $\mathrm{Al}$ powders occurs, particles of a soft element, in our case $\mathrm{Al}$, envelop Ti particles, forming a plastic matrix on the substrate surface. Under the influence of ball impacts in the surface layer, a lamellar structure is formed from flattened particles of powder components. A detailed image indicates the viscous behavior of the material in MF. The cellular structure in some areas, observed at high magnifications, confirms the flow of the material during processing (Figs. 1 and 2).

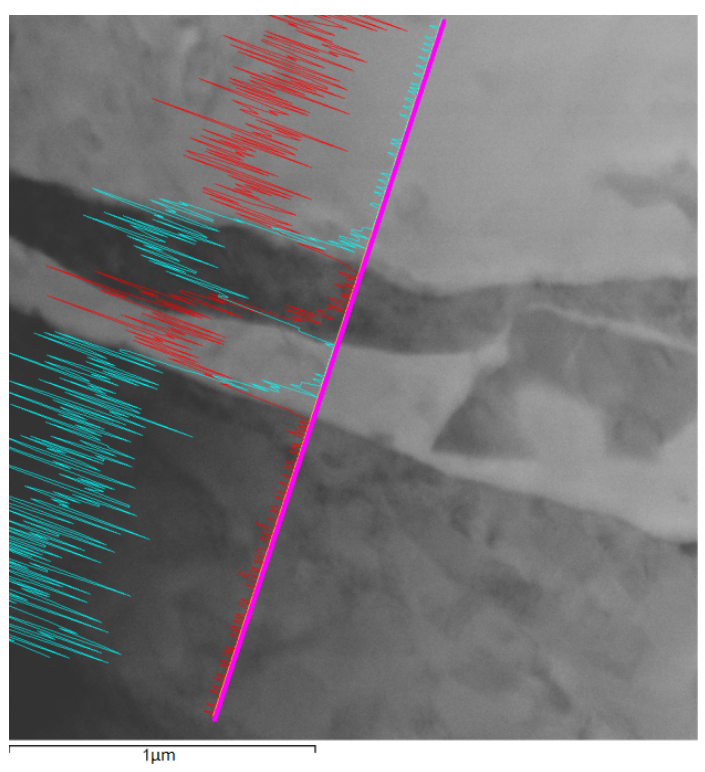

a)

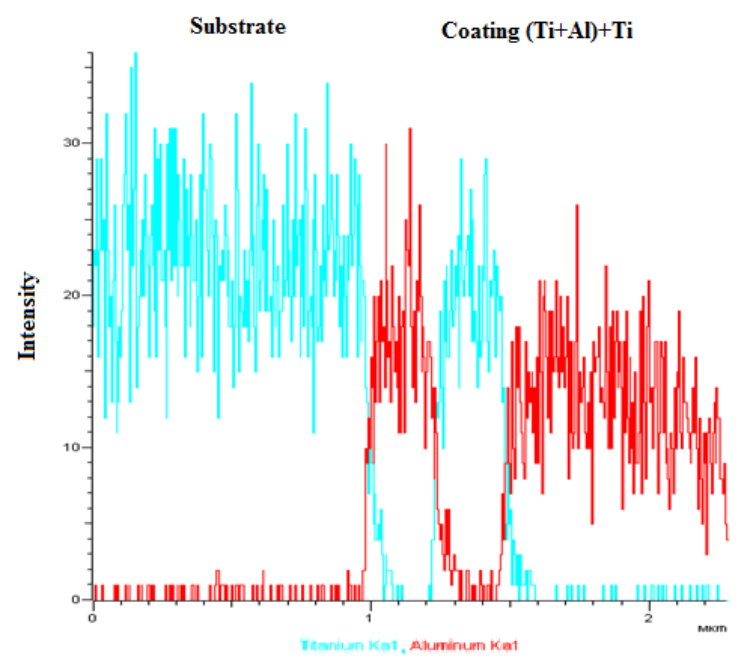

b)

Fig. 3. Ti-Al coating on the surface of Ti: a) - cross section, b) - concentration profile

Spectra of energy dispersive analysis were taken from the cross section. The results of the decoding of the spectra are shown in Fig. 4 a, b. 


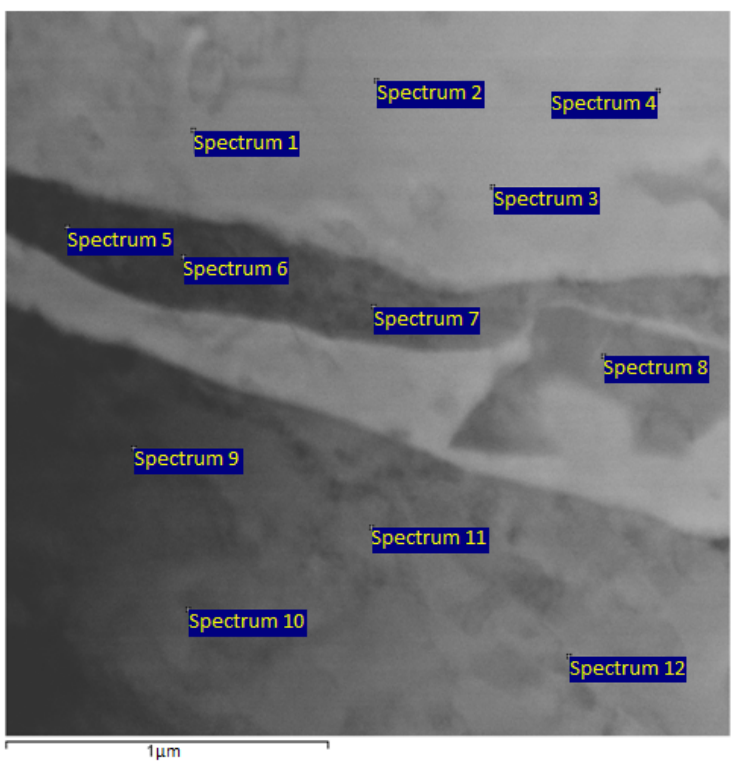

a)

\begin{tabular}{|l|l|l|l|l|}
\hline Spectrum & $\begin{array}{l}\text { In } \\
\text { stat. }\end{array}$ & $\mathrm{Al}$ & $\mathrm{Si}$ & $\mathrm{Ti}$ \\
\hline Specrtum 1 & Yes & 98.56 & 0.81 & 0.63 \\
\hline Specrtum 2 & Yes & 97.98 & 1.41 & 0.60 \\
\hline Specrtum 3 & Yes & 98.34 & 0.90 & 0.75 \\
\hline Specrtum 4 & Yes & 95.65 & 3.19 & 1.16 \\
\hline Specrtum 5 & Yes & 5.99 & 1.65 & 92.36 \\
\hline Specrtum 6 & Yes & 5.04 & 2.00 & 92.96 \\
\hline Specrtum 7 & Yes & 6.60 & 2.19 & 91.22 \\
\hline Specrtum 8 & Yes & 0.83 & 8.62 & 90.55 \\
\hline Specrtum 9 & Yes & 1.14 & 1.53 & 97.34 \\
\hline Specrtum 10 & Yes & 0.86 & 2.49 & 96.66 \\
\hline Specrtum 11 & Yes & 1.35 & 1.85 & 96.80 \\
\hline Specrtum 12 & Yes & 1.49 & 3.59 & 94.92 \\
\hline Average & & 34.49 & 2.52 & 62.99 \\
\hline $\begin{array}{l}\text { Standard } \\
\text { deviation }\end{array}$ & & 46.69 & 2.09 & 45.99 \\
\hline Max & & 98.56 & 8.62 & 97.34 \\
\hline Min & & 0.83 & 0.81 & 0.60 \\
\hline
\end{tabular}

b)

Fig. 4. Interpretation of spectra from the cross section shown in Fig. 1

Deciphering the microdiffraction pattern from the substrate surface (Fig. $5 \mathrm{a}, \mathrm{b}$ ) showed that, as a result of mechanochemical fusion, a $\mathrm{TiAl}_{3}$ phase with a bcc lattice (structure $I 4 / \mathrm{mmm}$ ) was detected. This corresponds to the stable state of the $\mathrm{TiAl}_{3}$ alloy. The presence of reflections of the atomically ordered structure of $L 1_{2}$ was found, which corresponds to the metastable state of $\mathrm{TiAl}_{3}$. This can be explained by the fact that under mechanical alloying the structure $14 / \mathrm{mmm}$ transforms into the structure $L 1_{2}$.

The processes of structural-phase transitions under extreme conditions of mechanochemical fusion proceed according to the principle of maximum entropy production. As a result, the entropy of the resulting structures can be negative. This is possible due to the switching of chemical bonds in the process of mechanochemical reactions that occur in time $120 \mathrm{~min}$, and the switching time of chemical bonds is from $10^{-10}-10^{-13} \mathrm{~s}$.

It was shown in [5-12] that the formation of cubic $\mathrm{Al}_{3} \mathrm{Ti}(c P 4)$ was detected in thin films deposited from vapors [5], mechanically doped [6-9] and rapidly solidified [10] samples. Tetragonal $\mathrm{Al} 3 \mathrm{Ti}\left(\mathrm{Al}_{3} \mathrm{Ti}(t I 16)\right.$ forms a metastable phase in the temperature range $495-800^{\circ} \mathrm{C}$ upon heating of mechanically doped cubic $\mathrm{Al}_{3} \mathrm{Ti}(c P 4)$ [11]. Above $800^{\circ} \mathrm{C}, \mathrm{Al}_{3} \mathrm{Ti}(t I 16)$ transforms into the equilibrium structure of $\mathrm{Al}_{3} \mathrm{Ti}(t I 8)$. Another form of $\mathrm{Al}_{3} \mathrm{Ti}$, is $\mathrm{Al}_{3} \mathrm{Ti}$ (tI64), which is regarded as the superstructure of $\mathrm{Al}_{3} \mathrm{Ti}(t I 8)$, which was observed in diffusion pairs [12]. A recent study of phase equilibria in Al-Ti [10] using bulk alloy samples has not confirmed the stability of this structure. Therefore, the authors of [1] consider $\mathrm{Al}_{3} \mathrm{Ti}$ (tI64) as a metastable phase, possibly stabilized by the action of voltage.

Indeed, the atomic volumes of $\mathrm{Al}_{3} \mathrm{Ti}$ phases for various modifications are presented in [1], where it was shown that the volume of the metastable phase with structure $L 1_{2}$ is much smaller than the volume of the stable phase $I 4 / \mathrm{mmm}$, i.e. the phase with the $L 1_{2}$ structure has a higher 


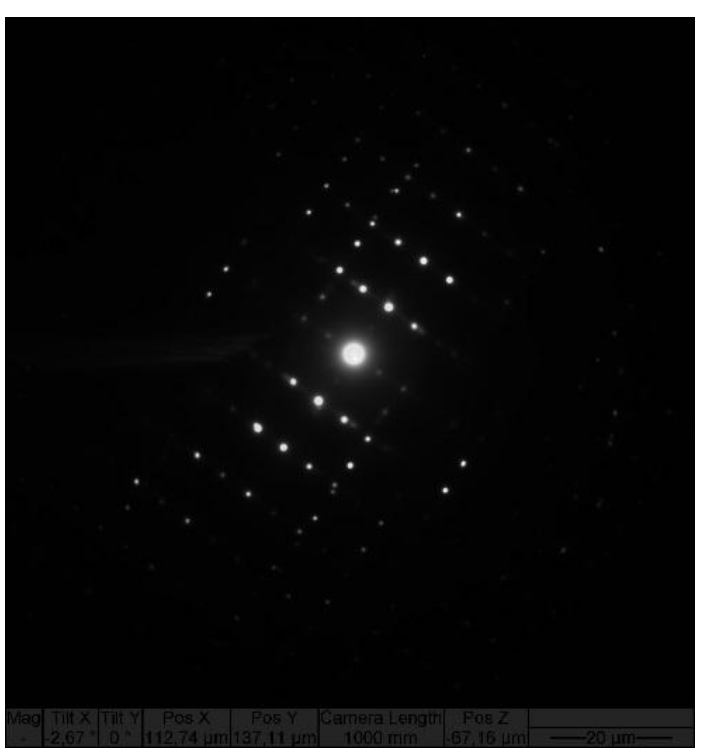

a)

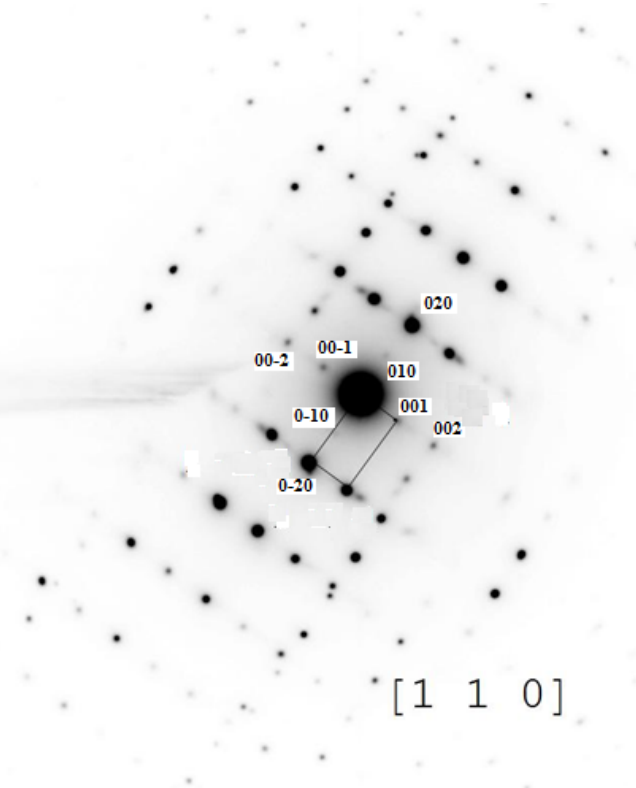

b)

Fig. 5. (a) - Microdiffraction pattern of the surface of a titanium substrate treated with particles of $\mathrm{Al}+\mathrm{Ti}$ powder. (b) - Scheme of deciphering the diffraction pattern in which superstructural reflexes are present

specific strength compared to the phase with the $I 4 / \mathrm{mmm}$ structure. In this way, the possibility of hardening the surface layers (Ti-Al) $+\mathrm{Ti}$ by mechanochemical fusion was found in the work. Hardening is associated with the polymorphic transformation of the stable phase $I 4 / \mathrm{mmm}$ into the metastable phase $L 1_{2}$.

\section{References}

[1] G.Ghosh, M.Asta, Acta Mater., 53(2005), no. 11, 3225-3252.

DOI: $10.1016 /$ j.actamat.2005.03.028

[2] J.H.Westbrook, R.L.Fleischer, Strustural Application of Intermetallic Compounds. New York, Wiley, 1994.

[3] V.V.Boldyrev, Success of the chemistry, 75(2006), no. 3, 177-189.

DOI: 10.1070/RC2006v075n03ABEH001205

[4] V.M.Klyarovsky, V.I.Molchanova, Mechanochemical phenomena during ultrafine grinding, Novosibirsk, Nauka, 1971 (in Russian).

[5] Q.Z.Hong, D.A.Lilienfeld, J.W.Mayer, Thermal and ion-induced, metastable-cubic $\mathrm{Al}_{3} \mathrm{M}$ phases in Al-Ti and Al-Hf thin films, J. Appl. Phys., 64(1988), no. 9, 4478-4488.

[6] S.Srinivasan, P.B.Desch, R.B.Schwarz, Metastable phases in the $\mathrm{Al}_{3} \mathrm{X}(\mathrm{X}=\mathrm{Ti}, \mathrm{Zr}$, and $\mathrm{Hf}$ ) intermetallic system, Scripta Metall. Mater., 25(1991), no. 11, 2513-2516. 
[7] G.M.Janowski, G.R.Stafford, The microstructure of electrodeposited titanium-aluminum alloys, Metall. Trans. A, 23(1992), no. 10, 2715-2723.

[8] R.B.Schwartz, P.B.Desch, S.Srinivasan, P.Nash, Synthesis and properties of trialuminides with ultra-fine microstructures, Nanostruct. Mater., 1(1992), no. 1, 37-42.

[9] M.Oehring, T.Klassen, R.Bormann, The formation of metastable $\mathrm{Ti}-\mathrm{Al}$ solid solutions by mechanical alloying and ball milling, J. Mater. Res., 8(1993), 2819-2829.

[10] J.Braun, M.Ellner, Phase equilibria investigations on the aluminum-rich part of the binary system Ti-Al, Metall. Mater. Trans., 32(2001), no. 5, 1037-1047.

[11] S.Srinivasan, P.B.Desch, R.B.Schwarz, Metastable phases in the $\mathrm{Al}_{3} \mathrm{X}$ (X $=\mathrm{Ti}$, Zr, and Hf) intermetallic system, Scripta Metall. Mater., 25(1991), no. 12, 2513-2516.

[12] J.Maas, G.Bastin, F.Van Loo, R.Metselaar, On the texture in diffusion grown layers of silicides and germanides with the $\mathrm{FeB}$ structure, $\mathrm{MeX}(\mathrm{Me}=\mathrm{Ti}, \mathrm{Zr} ; \mathrm{X}=\mathrm{Si}, \mathrm{Ge})$ or the $\mathrm{ZrSi}_{2}$ structure ( $\mathrm{ZrSi}_{2}, \mathrm{HfSi}_{2}, \mathrm{ZrGe}_{2}$ ), Z METALLK, 74(1983), 294-298.

\title{
Исследование тонкой структуры Ti-Al покрытий на поверхности $\mathrm{Ti}$, полученных методом механического сплавления
}

\author{
Жулдыз Б. Сагдолдина \\ Бауржан К. Рахадилов \\ Риза Б. Абылкалыкова \\ Восточно-Казахстанский государственный университет \\ Усть-Каменогорск, Казахстан \\ Людмила И. Квеглис \\ Павел О.Шалаев \\ Сибирский федеральный университет \\ Красноярск, Российская Федерация \\ Рауан С. Кожанова \\ Восточно-Казахстанский государственный университет \\ Усть-Каменогорск, Казахстан
}

\begin{abstract}
Аннотация. Работа посвящена исследованию структурно-фазовых превращений в композиционных покрытиях (Ti-Al)+Ti при механическом сплавлении. Получены данные о структурнофазовых состояниях (Ti-Al)-Tі покрытий после механического сплавления, подтверждающие механизм формирования модифицированного слоя за счет деформационного уплотнения частиц порошка на поверхности титана под механическим воздействием. В результате механохимического сплавления обнаружена фаза $\mathrm{TiAl}_{3}$ с ОЦК-решеткой (структура $I 4 / \mathrm{mmm}$ ), что соответствует стабильному состоянию сплава $\mathrm{TiAl}_{3}$. В условиях механического сплавления структура $I 4 / \mathrm{mmm}$ переходит в структуру $L 1_{2}$, что соответствует метастабильному состоянию $\mathrm{TiAl}_{3}$.

Ключевые слова: структурно-фазовые превращения, композиционные покрытия, механическое сплавление, твердофазные процессы.
\end{abstract}

